Original Research Paper

\title{
Studi Analisis Kualitas Air Sungai Brangbiji Sumbawa Besar
}

\author{
Dwi Mardhia $^{1 *}$, Viktor Abdullah ${ }^{1}$ \\ ${ }^{1}$ Fakultas Peternakan dan Perikanan, Universitas Samawa
}

\author{
Article history \\ Received: October $5^{\mathrm{s}} \mathrm{t}, 2018$ \\ Revised: October 28 ${ }^{\text {st }}, 2018$ \\ Accepted: November $4^{\text {st }}, 2018$ \\ Published: November $21^{\text {st }}$, \\ 2018
}

*Corresponding Author:

Dwi Mardhia,

Fakultas Peternakan dan

Perikanan, Universitas

Samawa, Indonesia;

Email:

kemang.kuneng@gmail.com
Abstract:One of the potential sources pollution of the Brangbiji River is the presence of a number of industrial tofu tempe. The industry produces liquid wastes characterized by a high content of organic matter and BOD / COD. The waste is immediately dumped into the Brangbiji River without any prior treatment, which could potentially pollute the Brangbiji River. The purpose of this study was 1) to analyze the quality of wastewater from the tempe tofu industry at Brangbiji village, 2) to analyze the water quality of the Brangbiji River, 3) to analyze the quality of tempe tofu industry wastewater effects on the water quality of the Brangbiji River, 4) to develop a management strategy of tofu tempe industry wastewater management. The method used in the research is the survey method, the purpose of the study is the quality of wastewater from the tempe-tofu industry and the water quality of the Brangbiji River. Determination of the sample by purposive sampling. The analysis of the data was done in a descriptive and qualitative way. The results showed that all tempe-tofu industrial wastewater samples for $\mathrm{pH}$, temperature, TDS, TSS, BOD, COD and ammonia parameters exceeded the quality standards. The water quality of the Brangbiji River based on $\mathrm{pH}$, temperature, TDS, TSS, BOD, COD and ammonia parameters exceeds the water quality standards of Classes 1 and 2 , but still meets quality standards. Class 3 and 4 water on increasing the concentration of TSS, BOD, COD and ammonia parameters in the lower river. The environmental management strategy that can be put in place is the provision of communal wastewater treatment plants, the use of waste in other useful forms and the need to systematically monitor the quality of the Brangbiji River.

Keywords: wastewater, tempe-tofu Industry, Brangbiji river

Abstrak: Salah satu sumber yang berpotensi mencemari sungai Brangbiji adalah keberadaan sejumlah indutri tahu tempe. Industri tersebut menghasilkan limbah cair dengan karakteristik mengandung bahan organik tinggi dan kadar BOD, COD yang cukup tinggi. Limbah tersebut langsung dibuang ke Sungai Brangbiji tanpa melalui suatu pengolahan terlebih dahulu, hal ini berpotensi besar mencemari sungai Brangbiji. Tujuan penelitian ini adalah 1) menganalisis kualitas limbah cair industri industri tahu tempe di Kelurahan Brangbiji, 2) menganalisis kualitas air sungai Brangbiji, 3) menganalisis pengaruh limbah cair industri tahu tempe terhadap kualitas air sungai Brangbiji, 4) merumuskan strategi pengelolaan lingkungan penanganan limbah cair industri tahu tempe. Metode yang digunakan dalam penelitian adalah metode survey, obyek kajiannya adalah kualitas air limbah industri tahu tempe dan kualitas air sungai Brangbiji. Penentuan sampel secara purposive sampling. Analisis data dilakukan secara deskriptif kualitatif. Hasil penelitian menunjukkan semua sampel air limbah industri tahu tempe untuk parameter $\mathrm{pH}$, suhu, TDS, TSS, BOD, COD dan ammonia melebihi baku mutu. Kualitas air sungai Brangbiji berdasarkan parameter $\mathrm{pH}$, suhu, TDS, TSS, BOD, COD dan ammonia melebihi baku mutu air kelas 1 dan 2 tetapi masih memenuhi baku mutu air kelas 3 dan 4. Pengaruh limbah industri tahu tempe terhadap kualitas air sungai Brangbiji dapat dilihat pada peningkatan konsentrasi parameter TSS, BOD, COD dan ammonia pada bagian hilir sungai. Adapun strategi pengelolaan lingkungan yang 
dapat dilakukan adalah penyediaan IPAL Komunal, pemanfaatan limbah menjadi bentuk lain yang bermanfaat dan perlu adanya monitroring rutin kualitas sungai Brangbiji.

Kata kunci: limbah cair, Industri tahu tempe, Sungai Brangbiji

\section{Pendahuluan}

Menurut Buchori et al (2012) kebutuhan terhadap kedelai mencapai 2,3 juta ton per tahun, dimana $50 \%$ dikonsumsi sebagai tempe, $40 \%$ berupa tahu dan $10 \%$ berupa minyak kedelai. Tahu dan tempe merupakan jenis makanan sumber protein berbahan dasar kacang kedelai dengan harga murah namun bergizi tinggi. Masyarakat di Sumbawa gemar mengkonsumsi tahu dan tempe sehingga dalam memenuhi kebutuhan akan tahu dan tempebanyak berkembang industri tahu tempe. Industri tahu tempe yang ada di Sumbawa merupakan industri kecil skala rumah tangga. Jumlah industri tahu tempe di Kabupaten Sumbawa adalah 40 industri yang tersebar di 4 kecamatan yaitu sebanyak 6 industri di kecamatan Lape, 20 industri di kecamatan Sumbawa, 8 industri di kecamatan Alas dan 6 industri di kecamatan Plampang (BPS Kab. Sumbawa, 2016). Kelurahan Brangbiji merupakan lokasi sentra industri tahu tempe di Kecamatan Sumbawa. Lokasi sentra industri tersebut berada di sepanjang bantaran sungai Brangbiji.Sumber daya manusia yang terlibat pada industri tahu tempe umumnya bertaraf pendidikan yang relatif rendah, serta belum banyak yang melakukan pengolahan limbah atau memanfaatkan limbahnya dengan baik. Pada saat ini semua industri tahu tempedi bantaran sungai Brangbiji masih merupakan industri kecil skala rumah tangga yang tidak dilengkapi dengan unit pengolah air limbah. Limbah cair yang dihasilkan dari industri ini langsung dibuang ke sungai Brangbiji tanpa melalui pengolahan terlebih dahulu. Hal ini akan mempengaruhi kualitas air sungai Brangbiji.

Limbah industri tahu tempe berupa limbah padat maupun limbah cair. Limbah padat dihasilkan dari proses penyaringan dan penggumpalan, limbah ini kebanyakan dijual dan diolah menjadi tempe gembus dan pakan ternak. Sedangkan limbah cairnya dihasilkan dari proses pencucian, perebusan, pengepresan dan pencetakan tahu, oleh karena itu limbah cair yang dihasilkan dari industri tahu dan tempe volumenya cukup tinggi. Limbah cair tahu tempe dengan karakteristik mengandung bahan organik tinggi dan kadar BOD, COD yang cukup tinggi pula, jika langsung dibuang ke badan air, maka akan menurunkan daya dukung lingkungan pada perairan tersebut (Agung dan Hanry, 2013). Industri tahu tempe umumnya berlokasi di sekitar badan air. Hal ini dikarenakan lokasi dekat dengan badan air memudahkan industri tersebut untuk memenuhi kebutuhan air untuk proses produksi dan memudahkan dalam proses pembuangan limbah cairnya. Industri yang terletak di kelurahan Brangbiji menghasilkan limbah cair yang langsung dibuang ke sungai Brangbiji tanpa melalui pengolahan terlebih dahulu. Hal ini tentu akan mempengaruhi kualitas dan mencemari sungai Brangbiji.

Sungai merupakan sumber air permukaan yang memberikan manfaat kepada kehidupan manusia. Kualitas sungai akan mengalami perubahan-perubahan sesuai dengan perkembangan lingkungan sungai yang dipengaruhi oleh berbagai aktivitas dan kehidupan manusia. Beberapa pencemaran sungai tentunya diakibatkan oleh kehidupandisekitarnya baik pada sungai itu sendiri maupun perilaku manusia sebagai pengguna sungai. Pengaruh dominan terjadinya pencemaran yang sangat terlihat adalahkerusakan yang diakibatkan oleh manusia tergantung dari polakehidupannya dalam memanfaatkan alam. Setiap pinggiran sungai yang dekat dengan pabrik atau daerah perindustrian, dipastikan akan terlihat saluran-saluran buangan yang menuju ke badansungai. Sehingga apabila dikumulatifkan dari beberapa outlet buangan maka akanmenjadikan buangan yang cukup tinggi pada badan sungai tersebut. Akibat buangan dari aktivitas limbah yang datang dari daerah industri menyebabkan terganggunya ekosistem sungai. Ikan banyak yang mati, air berubah 
warna, menimbulkan bau, pemandangan terganggu dan menimbulkan masalah kesehatan manusia. Masalah tersebut timbul dikarenakan ketidakmampuan daya dukung sungai untuk mengadakan netralisasi.

Perwujudan dari pembangunan berkelanjutan terhadap pertumbuhan industri adalah dengan adanya kebutuhan akan industri berwawasan lingkungan. Industri Berwawasan Lingkungan adalah untuk memperbaiki kinerja ekonomi bagi industri-industri di dalamnya dengan cara meminimalkan dampak lingkungannya (Sarengat et al, 2015). Kondisi di Indonesia tak terkecuali di Sumbawa adalah masih banyak industri yang belum bisa menerapkan sistem yang ramah terhadap lingkungan sehingga akan mempengaruhi kualitas lingkungan di lokasi tersebut.

Industri tahu tempe di Kabupaten Sumbawa yang berwawasan lingkungan perlu diwujudkan melalui suatu upaya untuk mengatur pola industrialisasi tahu tempeagar tetap berkembang pesat tetapi pencemarannya dapat dikendalikan dalam batas-batas daya dukung lingkungan alam di sekelilingnya sehingga terjamin kelestariannya. Sampai saat ini belum diketahui sampai sejauh mana potensi dan tingkat pencemaran yang diakibatkan oleh aktifitas industri tahu tempedalam kaitannya dengan upaya pengembangan industri tahu tempe di Kabupaten Sumbawa. Oleh karena itu perlu ada penelitian untuk mengetahui pengaruh limbah cair industri tahu tempe terhadap kualitas sungai Brangbiji. Hasil penelitian tersebut diharapkan dapat memberikan data bagi pemerintah untuk digunakan sebagai bahan pertimbangan dalam menetapkan kebijakan pengembangan industri tahu tempe yang berwawasan lingkungan di Kabupaten Sumbawa

\section{Bahan dan Metode}

\section{Lokasi dan Waktu Penelitian}

Penelitian ini mulai dilaksanakan pada bulan Pebruari hingga Juli 2018di kelurahan Brangbiji meliputi dua lokasi sampling yaitu (1) Industri Tahu Tempe yang berada di bantaran Sungai Brangbiji dan (2) sungai Brangbiji. Pemlilihan lokasi didasarkan pertimbangan lokasi merupakan sentra industri tahu tempe di Kabupaten Sumbawa dan menghasilkan limbah cair yang langsung dibuang ke sungai Brangbiji tanpa melalui pengolahan terlebih dahulu, sehingga berpotensi mencemari sungai Brangbiji. Sungai Brangbiji sendiri merupakan sungai yang melintasi Kota Sumbawa dan dimanfaatkan sebagai sumber air bersih warga disekitarnya untuk mandi, mencuci, sumber air untuk kegiatan peternakan, mengairi tanaman hingga media penanaman kangkung. Melihat aspek lokasi sungai dan pemanfaatannya maka kebersihan dan kualitas air sungai Brangbiji perlu dijaga kualitasnya, kelestarian dan kondisi fisiknya karena kebersihan sungai ini menjadi wajah kota Sumbawa.

\section{Desain Penelitian}

Metode yang digunakan dalam penelitian ini adalah metode survey dengan pengukuran langsung di lapangan, analisis laboratorium dan wawancara untuk memperoleh fakta-fakta dari gejala-gejala yang ada dan mencari keteranganketerangan secara faktual, mengenal masalahmasalah serta mendapatkan pembenaran terhadap keadaan dan praktek-praktek yang sedang berlangsung terkait pencemaran industri tahu tempe. Yang menjadi obyek kajian adalah kualitas limbah cair industri tahu tempe dan kualitas air sungai Brangbiji. Pengumpulan data dilakukan melalui sampling limbah cair industri tahu tempe dan sampling.

\section{Teknik Pengumpulan Data}

Penentuan sampel limbah cair, air sungai dan sampel responden secara purposive sampling agar didapatkan sampel yang representatif. Pengambilan teknik ini didasarkan pada heterogenitas populasi, jumlah industri tahu tempe dan pertimbangan pengaruh limbah industri tahu tempe terhadap kualitas air sungai Brangbiji. Pengambilan sampel limbah cair industri tahu tempe dilakukan pada pipa akhir limbah cair yang akan dibuang ke sungai, sedangkan sampel air sungai diambil pada dua lokasi yaitu pada titik dimana belum ada pengaruh industri tahu tempe dan pada titik dimana air sungai sudah terpengaruh oleh limbah cair industri tahu tempe. Dengan demikian diharapkan dapat memberikan gambaran 
secara nyata pengaruh cemaran limbah cair industri tahu tempe.

\section{Analisis Data}

Analisis data menggunakan metode deskriptif kualitatif dengan menggunakan tabulasi dan narasi untuk menjelaskan kualitas limbah cair industri tahu tempe, kualitas air sungai Brangbiji, pengaruh cemaran limbah cair industri tahu tempe terhadap kulaitas air sungai Brangbiji serta merumuskan strategi pengelolaan lingkungan penanganan limbah cair industri tahu tempe.

Tabel 1. Variabel dan Teknik Analsis Data

\begin{tabular}{lll}
\hline Variabel & Teknik Analisis & Hasil \\
\hline Kualitas Limbah cair & Uji laboratorium (TDS, TSS, pH, Suhu, BOD, & $\begin{array}{l}\text { Kualitas limbah cair industry } \\
\text { tahu tempe }\end{array}$ \\
Kualitas air sungai Brangbij & $\begin{array}{l}\text { COD dan Amonia) } \\
\text { Uji laboratorium (TDS, TSS, pH, Suhu, BOD, }\end{array}$ & $\begin{array}{l}\text { Kualitas air sungai Brangbiji } \\
\text { COD dan Amonia) }\end{array}$ \\
- Kualitas limbah cair & $\begin{array}{l}\text { Analisis pengaruh limbah cair industri tahu } \\
\text { tempe terhadap kualitas air sungai Brangbiji }\end{array}$ & $\begin{array}{l}\text { Pengaruh limbah cair tahu tempe } \\
\text { terhadap kualitas air sungai } \\
\text { Brangbiji }\end{array}$ \\
\hline
\end{tabular}

Pada tahap ini dilakukan analisis data terhadap hasil analisis kualitas limbah cair industri tahu tempe dan kualitas air sungai Brangbiji dengan cara sebagai berikut:

1. Analisis kualitas limbah cair industri tahu tempe

Analisis ini dilakukan untuk mengetahui kualitas limbah cair industri tahu tempe meliputi parameter BOD, COD, TSS, TDS, Amonia, $\mathrm{pH}$ dan temperatur, untuk dibandingkan dengan baku mutu limbah cair yang dipersyaratkan dalam PermenLH no 5 tahun 2014, apakah memenuhi baku mutu atau tidak dan apakah kualitas limbah cair berpotensi besar mencemari air sungai Brangbiji.

2. Analisis kualitas air sungai Brangbiji

Analisis ini dilakukan untuk mengetahui kualitas air sungai Brangbiji sebelum adanya pengaruh dari industri tahu tempe untuk melihat kualitas air sungai Brangbiji sebelum mendapat masukan dari limbah cair industri tahu tempe. Analisis juga dilakukan untuk mengetahui kualitas air sungai Brangbiji setelah mendapat masukan dari limbah industri tahu tempe. Hasil analisis kualitas air dibandingkan dengan persyaratan sesuai PP no 82 tahun 2001.
3. Analisis pengaruh limbah cair industri tahu tempe terhadap kualitas air sungai Brangbiji. Analisis ini dilakukan dengan membandingkan kualitas limbah cair industri tahu tempe dan kualitas air sungai Brangbiji sebelum dan sesudah mendapat masukan dari limbah cair industri tahu tempe untuk mengetahui pengaruh cemaran limbah cair industri tahu tempe terhadap air sungai Brangbiji

\section{Hasil dan Pembahasan}

\section{Kualitas Lmbah Cair Industri Tahu Tempe}

Kualitas limbah cair industri tahu tempe digambarkan oleh parameter kunci meliputi parameter BOD, COD, TSS, TDS, Amonia, $\mathrm{pH}$ dan temperatur (Kaswinarni, 2007).Pengambilan sampel air limbah industri tahu tempe yang membuang limbahnya ke sungai Brangbiji dilakukan pada pipa outlet pembuangan limbah industri tahu tempe. Untuk memastikan kualitas limbah yang keluar dari outlet adalah hanya berasal dari limbah industri tahu tempe maka dilakukan pengujian terhadap limbah industri tahu, limbah industri tempe dan limbah industri tahu tempe sebagai sampel kontrol. Adapun hasil pengujian laboratorium terhadap sampel limbah industri tahu tempe adalah sebagai berikut: 
Tabel 2. Hasil Analisis Kualitas Limbah Industri Tahu Tempe

\begin{tabular}{|c|c|c|c|c|c|}
\hline \multirow{2}{*}{ Parameter } & \multicolumn{4}{|c|}{ Titik Sampling } & \multirow[t]{2}{*}{ Baku mutu } \\
\hline & 01 & 02 & 03 & 04 & \\
\hline Suhu & $80^{\circ} \mathrm{C}$ & $70^{\circ} \mathrm{C}$ & $32{ }^{\circ} \mathrm{C}$ & $35^{\circ} \mathrm{C}$ & $45^{\circ} \mathrm{C}$ \\
\hline Residu tersuspensi & $1850 \mathrm{mg} / \mathrm{l}$ & $1720 \mathrm{mg} / \mathrm{l}$ & $312 \mathrm{mg} / \mathrm{l}$ & $1910 \mathrm{mg} / \mathrm{l}$ & $200 \mathrm{mg} / \mathrm{l}$ \\
\hline $\mathrm{pH}$ & $3,62 \mathrm{mg} / \mathrm{l}$ & $4,56 \mathrm{mg} / \mathrm{l}$ & $5,56 \mathrm{mg} / \mathrm{l}$ & $4,56 \mathrm{mg} / 1$ & $6 \mathrm{~s} / \mathrm{d} 9$ \\
\hline BOD & $1130 \mathrm{mg} / 1$ & 486 mg/l & $292 \mathrm{mg} / \mathrm{l}$ & $1302 \mathrm{mg} / \mathrm{l}$ & $150 \mathrm{mg} / \mathrm{l}$ \\
\hline COD & $1900 \mathrm{mg} / 1$ & $728 \mathrm{mg} / \mathrm{l}$ & $378 \mathrm{mg} / \mathrm{l}$ & $655 \mathrm{mg} / \mathrm{l}$ & $300 \mathrm{mg} / \mathrm{l}$ \\
\hline Residu terlarut & $2390 \mathrm{mg} / 1$ & $1480 \mathrm{mg} / \mathrm{l}$ & $626 \mathrm{mg} / \mathrm{l}$ & $2230 \mathrm{mg} / \mathrm{l}$ & $0 \mathrm{mg} / \mathrm{l}$ \\
\hline Amonia & $84,8 \mathrm{mg} / 1$ & $83,4 \mathrm{mg} / \mathrm{l}$ & $0,115 \mathrm{mg} / \mathrm{l}$ & $84,8 \mathrm{mg} / 1$ & $0 \mathrm{mg} / \mathrm{l}$ \\
\hline
\end{tabular}

Berdasarkan hasil analisis kualitas limbah industri tahu tempe pada tabel diatas menunjukkan semua parameter melebihi baku mutu kecuali untuk parameter suhu pada sampel 3 dan 4. Hasil tersebut mengindikasikan bahwa limbah industri tahu tempe berpotensi mencemari lingkungan perairan dalam hal ini sungai Brangbiji.

Suhu limbah cair industry tahu tempe yang berasal dari rebusan kedelai berdasarkan hasil pengukuran menunjukkan angka mencapai $80{ }^{\circ} \mathrm{C}$. limbah tersebut langsung dibuang ke sungai Brangbiji tanpa ada proses pendiaman/pendinginan terlebih dahulu. Apabila setiap hari sungai Brangbiji memperoleh pasokan limbah cair dengan suhu yang tinggi tersebut maka akan membahayakan kehidupan organisme air yang ada di sungai Brangbiji. Adapun suhu yang optimum untuk kehidupan organisme dalam air adalah $25 \mathrm{~s} / \mathrm{d}$ $30{ }^{\circ} \mathrm{C}$. Adanya masukan limbah dengan suhu yang tinggi akan mempengaruhi suhu air sungai Brangbiji. Air sungai Brangbiji suhunya menjadi naik dan akan mengganggu kehidupan hewan maupun tanaman air mengingat kadar oksigen terlarut akan turun bersamaan dengan kenaikan suhu. Disamping berpengaruh terhadap kehidupan organisme perairan, peningkatan suhu sungai Brangbiji juga akan berpengaruh terhadap kehidupan tumbuhan air karena pertumbuhan tumbuhan air akan terhenti pada suhu air $<10{ }^{\circ} \mathrm{C}$ atau $>40{ }^{\circ} \mathrm{C}$ (Dahruji et al, 2017). Oksigen terlarut memiliki hubungan timbal balik dengan laju pernapasan mahkluk hidup. Peningkatan suhu akan berpengaruh terhadap peningkatan laju pernapasan makhluk hidup dan mengakibatkan penurunan oksigen terlarut dalam air.

Nilai residu terlarut (TDS) dan residu tersuspensi (TSS) limbah cair industry tahu tempe yang tertinggi adalah pada sampel outlet limbah (sampel 04) dan pada sampel air rebusan kedelai. Limbah cair dari semua sampel mempunyai nilai
TDS dan TSS yang jauh melewati baku mutu limbah cair. Pengaruh parameter TDS dan TSS terhadap lingkungan perairan sangat beragam, hal ini dipengaruhi oleh sifat kimia alamiah bahan tersuspensi tersebut. Pengaruh peningkatan konsentrasi TDS dan TSS terhadap ikan, zooplankton maupun makhluk hidup lain yang ada di perairan adalah terjadinya penyumbatan insang oleh partikel-partikel yang menyebabkan afiksiasi, adanya pengaruh pada perilaku ikan dan penolakan terhadap air yang keruh, adanya hambatan makan serta peningkatan pencarian tempat berlindung (Angarini dkk, 2014). Pola yang ditemukan pada sungai yang menerima sebagian besar padatan tersuspensi, secara umum adalah berkurangnya jumlah spesies dan jumlah individu makhluk hidup.

pH limbah industry tahu tempe pada ke 4 lokasi sampel menunjukkan nilai yang tidak memenuhi baku mutu. Semua $\mathrm{pH}$ sampel menunjukkan angka dibawah 6 , ini menunjukkan bahwa dilihat berdasarkan derajat keasaman maka limbah tersebut tergolong asam. Nilai $\mathrm{pH}$ industry tahu tempe yang masuk ke perairan berkisar pada nilai 3,62 s/d 5,56/ Air limbah dari kegiatan industri tahu tempe yang dibuang ke perairan berpotensi mengubah $\mathrm{pH}$ air serta dapat mengganggu kehidupan organisme air.

Limbah dari pengolahan tahu dan tempe mempunyai kadar BOD sekitar 5.000 - 10.000 $\mathrm{mg} / \mathrm{l}$, COD 7.000 - $12.000 \mathrm{mg} / \mathrm{l}$ (Dahruji et al, 2017). Nilai Biological Oxygen Demand (BOD atau kebutuhan oksigen biologis) sampel menunjukkan hasil berkisar pada nilai $292 \mathrm{mg} / \mathrm{l}$ - $1302 \mathrm{mg} / \mathrm{l}$. Nilai ini jauh melebihi baku mutu yang dipersyaratkan sebesar $150 \mathrm{mg} / \mathrm{l}$. Tingginya nilai BOD tersebut menyebabkan jumlah oksigen yang dibutuhkan oleh mikroorganisme untuk mendegradasi limbah tersebut sangat besar. Bahan organik akan diuraikan oleh mikroorganisme menjadi gas $\mathrm{CO}_{2}, \mathrm{H}_{2} \mathrm{O}$ dan 
gas $\mathrm{NH}_{3}$. Bau busuk pada perairan diakibatkan oleh keberadaan Gas $\mathrm{NH}_{3}$.

Nilai Chemical Oxigen Demand (COD) atau kebutuhan oksigen kimiawi) sampel menunjukkan angka yang berkisar $378 \mathrm{mg} / \mathrm{l}-1900$ $\mathrm{mg} / \mathrm{l}$. Nilai ini melebihi baku mutu yang dipersyaratkan sebsar $300 \mathrm{mg} / \mathrm{l}$. Kondisi ini menyebabkan jumlahoksigen yang dibutuhkan oleh mikroorganisme untuk mengoksidasi limbah melalui reaksi kimia sangat tinggi. Limbah organik akan dioksidasi oleh Kalium bikromat $\left(\mathrm{K}_{2} \mathrm{Cr}_{2} \mathrm{O}_{7}\right)$ menjadi gas $\mathrm{CO}_{2}$ dan $\mathrm{H}_{2} \mathrm{O}$ serta ion Chrom.

Bau busuk limbah industry tahu tempe berasal dari amoniak yang dihasilkan dari proses penguraian nitrogen dalam kondisi anaerobik. Bau menyengat dari amoniak sudah dapat tercium pada konsentrasi amoniak sebesar 0,037 mg/l (Wiryani, Erry. 2010). Nilai amoniak pada ke 4 sampel menunjukkan angka berkisar pada $0,115 \mathrm{mg} / \mathrm{l}-$ $84,8 \mathrm{mg} / \mathrm{l}$. Nilai ini jauh melebihi baku mutu, Hal ini mengakibatkan bau busuk pada sungai brangbiji dan tentu dapat membahayakan lingkungan perairan sungai Brangbiji. Keberadaan bahan buangan biodegradable dalam lingkungan perairan akan mengakibatkan terjadinya eutrifikasi yang berakibat pada menurunnya jumlah organisme perairan akibat kurangnya oksigen terlarut.

\section{Kualitas Air Sungai Brangbiji}

Tabel 3. Hasil Analisis Kualitas Air Sungai Brangbiji

\begin{tabular}{lllllll}
\hline \multirow{2}{*}{ Parameter } & Hasil & \multicolumn{3}{c}{ Baku mutu } & & \\
& Hilir & Hulu & kelas 1 & kelas 2 & kelas 3 & kelas 4 \\
\hline Residu tersuspensi & 176 & 143 & 50 & 50 s & 400 & 400 \\
pH & 7,5 & 6,5 & $6 \mathrm{~s} / \mathrm{d} 9$ & $6 \mathrm{~s} / \mathrm{d} 9$ & $6 \mathrm{~s} / \mathrm{d} 9$ & $5 \mathrm{~s} / \mathrm{d} 9$ \\
BOD & 8,24 & 7,04 & 2 & 3 & 6 & 12 \\
COD & 28,67 & 11,81 & 10 & 25 & 50 & 100 \\
Residu terlarut & 5,98 & 2,98 & 1000 & 1000 & 1000 & 2000 \\
Amonia & 0,288 & 0,0460 & 0,5 & 0 & 0 & 0 \\
\hline
\end{tabular}

Hasil analisis laboratorium menunjukkan adanya beberapa parameter yang melebihi baku mutu yang dipersyaratkan dalam PP no 82 tahun 2001. Analisis kualitas air sungai Brangbiji ditinjau berdasarkan parameter TSS menunjukkan bahwa konsentrasi TSS baik di hilir maupun di hulu sudah melebihi baku mutu air kelas 1 dan 2, tetapi masih memenuhi baku mutu air kelas 3 dan 4 . Dilihat perbandingan antara konsentrasi TSS di bagian hulu dan hilir menunjukkan bahwa konsentrasi TSS di bagian hilir lebih tinggi dibandingkan bagian
Penentuan kualitas air sungai jika dilihat berdasarkan pengaruh adanya sumber pencemar adalah dengan melakukan pengambilan sampel pada bagian yang belum terkena pengaruh pencemar dan pada bagian yang sudah terkena pengaruh cemaran (Hadi, 2005). Lokasi pengambilan sampel air sungai Brangbiji dilakukan pada dua titik yaitu:

1) Bagian hulu. Sampel air sungai diambil di bagian hulu sungai Brangbiji yang dipastikan tidak mendapat pengaruh dari limbah industri tahu tempe. Sampel diambil sebanyak 1 sampel dengan frekuensi pengambilan 1 kali.

2) Bagian hilir. Sampel diambil di bagian sungai yang sudah mendapat pengaruh dari limbah industri tahu tempe, tepatnya setelah pipa outlet IPAL. Penentuan lokasi sampel adalah sejauh $80 \mathrm{~m}$ dari pipa outlet dengan asumsi sudah mewakili konsentrasi pencampuran (air dan limbah)

Pemeriksaan kualitas air sungai Brangbiji mengikuti pemeriksaan parameter limbah industri tahu tempe meliputi BOD, COD, TSS, TDS, Amonia, $\mathrm{pH}$ dan temperatur. Hasil uji laboratorium kemudian dibandingkan dengan baku mutu sesuai PP no 82 tahun 2001. Adapun hasil pemeriksaan laboratoriu terhadap kualitas air sungai Brangbiji adalah sebagai berikut:

hulu. Parameter $\mathrm{pH}$ menunjukkan bahwa kualitas air masih memenuhi baku mutu karena berada pada rentang antara 6 sampai 9. Untuk parameter BOD menunjukkan bahwa ke dua sampel tidak memenuhi baku mutu air kelas 1, 2 dan 3, tetapi masih memenuhi baku mutu air kelas 4. Ditinjau dari konsentrasi COD menunjukkan bahwa kedua sampel tidak memenuhi baku mutu air kelas 1, sampel bagian hilir tidak memenuhi baku mutu air kelas 2, semua sampel memenuhi baku mutu air kelas 3 dan 4 . Konsentrasi TDS menunjukkan 
bahwa kedua sampel memenuhi baku mutu air kelas 1, 2, 3 dan 4. Konsentrasi ammonia menunjukkan bahwa kedua sampel tidak memenuhi baku mut air kelas 2, 3, dan 4 tetapi masih memenuhi baku mutu air kelas 1 .

\section{Pengaruh Limbah Cair Industri Tahu Tempe Terhadap Kualitas Air Sungai Brangbiji}

Keberadaan industri tahu tempe di sekitar sungai Brangbiji memberikan pengaruh terhadap kualitas air sungai Brangbiji. Hal tersebut dikarenakan limbah cair yang dibuang ke sungai Brangbiji kualitasnya melebihi baku mutu yang dipersyaratkan dan berpotensi besar mencemari kualitas perairan, Limbah yang dihasilkan oleh industri tahu tempe tersebut langsung masuk ke sungai Brangbiji tanpa melalui pengolahan terlebih dahulu. Limbah tersebut dialirkan melalui saluran dan mengalir ke sungai Brangbiji melalui pipa outlet.

Dilihat dari perbandingan kualitas air sungai Brangbiji bagian hulu dan bagian hilir, menunjukan adanya peningkatan semua nilai parameter pada bagian hilir. Bagian hilir merupakan lokasi yang mendapat masukan langsung limbah cair industri tahu tempe. Untuk lebih jelasnya dapat dilihat pada grafik berikut:

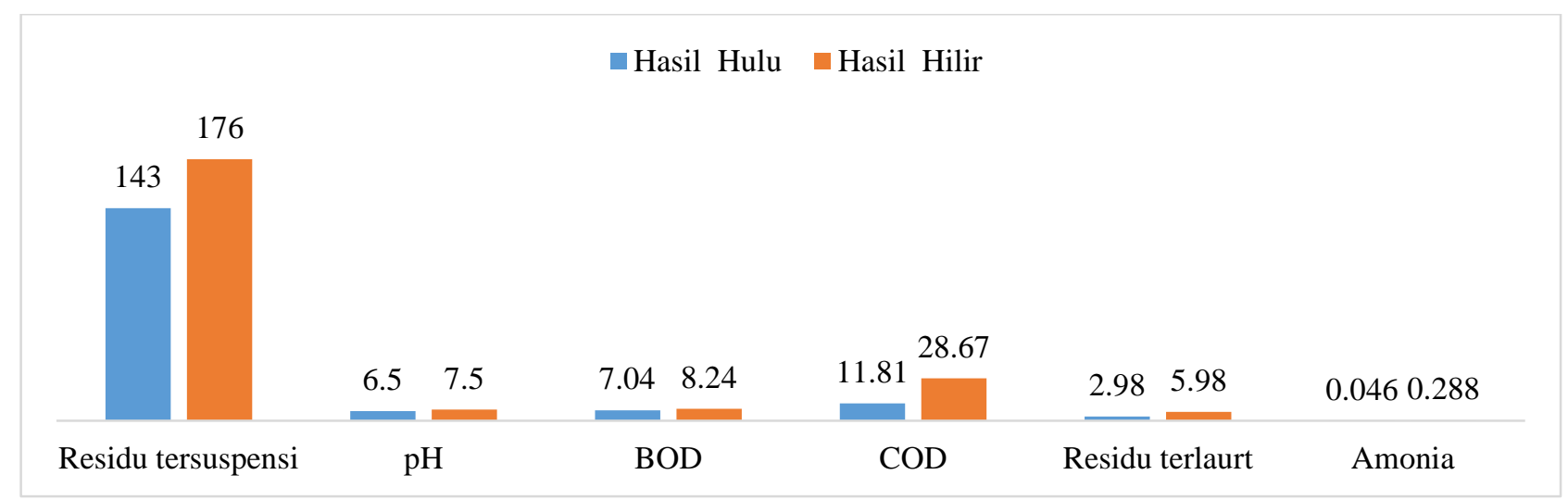

Gambar 2 Perbandingan Kualitas Air Sungai Brangbiji Hulu dan Hilir

Pengaruh limbah industri tahu tempe terhadap kualitas air sungai Brangbiji dapat dilihat pada peningkatan konsentrasi parameter TSS, BOD, COD dan ammonia pada bagian hilir. Dimana nilai perameter tersebut melebihi baku mutu air kelas 1, 2 dan 3.

\section{Strategi Pengelolaan Lingkungan Penanganan Limbah Cair Industri Tahu Tempe}

Limbah cair industri tahu tempe perlu ditangani secara efektif dan berkelanjutan. Penanganan limbah sebelum dibuang ke sungai perlu dilakukan dengan mengadakan unitIPAL Komunal melalui perencanaan, penerapan dan pemantauan yang lebih matang. Bentuk IPAL komunal yang diterapkan merupakan IPAL dengan kriteriabiaya investasi awal dan operasionalnya murah, perawatannya mudah, proses pengolahan lengkap (anaerobaerob), kualitas efluen memenuhi baku mutu air limbah industri tahu tempe, memiliki nilai ekonomis dan ramah lingkungan. Disamping pengolahan limbah pada sumbernya, pemanfaatan limbah menjadi produk lain seperti pupuk cair, biogas dan sebagainya merupakan cara efektif untuk mengurangi kuantitas limbah cair yang dibuang ke sungai. Strategi pengelolaan lingkungan lain yang perlu dilakukan dalam menjaga kualitas sungai Brangbiji adalah dengan melakukan monitoring secara rutin/periodik terhadap kualitas sungai Brangbiji. Kegiatan ini bertujuan untuk memantau pelaksanaan kegiatan pengolahan limbah melalui penerapan IPAL dan cleaner production yang diterapkan dalam mengatasi pencemaran oleh limbah industri tahu tempe.

\section{Kesimpulan}

Kualitas limbah cair industri tahu tempe berdasarkan pemeriksaan parameter kunci meliputi 
parameter $\mathrm{pH}$, suhu, TDS, TSS, BOD, COD dan ammonia menunjukkan hasil yang melebihi baku mutu. Hal ini akan mempengaruhi kualitas lingkungan perairan apabila limbahnya dibuang langsung ke sungai. Kualitas air sungai Brangbiji berdasarkan parameter $\mathrm{pH}$, suhu, TDS, TSS, BOD, COD dan ammonia melebihi baku mutu air kelas 1 dan 2 tetapi masih memenuhi baku mutu air kelas 3 dan 4. Limbah industri tahu tempe telah mempengaruhi kualitas air sungai Brangbiji. Pengaruh tersebut dapat dilihat pada peningkatan konsentrasi parameter TSS, BOD, COD dan ammonia pada bagian hilir sungai Brangbiji. Strategi pengelolaan lingkungan yang dapat dilakukan adalah penyediaan IPAL Komunal, pemanfaatan limbah menjadi bentuk lain dan monitroring rutin kualitas sungai Brangbiji.

\section{Ucapan Terima Kasih}

Ucapan terima kasih kami sampaikan kepada Kemenristekdikti yang telah membiayai pelaksanaan penelitian kami melalui hibah penelitian skeam Penelitian Dosen Pemula (PDP).

\section{Daftar Pustaka}

Agung, T R. \& Hanry S W. (2012). Pengolahan Limbah Industri Tahu dengan Menggunakan Teknologi Plasma. Jurnal Ilmiah Teknik Lingkungan. 02, 19-28.

Angraini., Mumu S., Yulianti P. (2014). Studi Pengolahan Limbah Usaha Mandiri Rumah Tangga dan Dampak Bagi Kesehatan di Wilayah Kenjeran. Reka Lingkungan: Jurnal ITN. 2, 1-10.

BPS Kab. Sumbawa., (2016). Kelurahan Brangbiji dalam Angka 2016. BPS Kab. Sumbawa. Sumbawa Besar.

Buchori, Luqman., Setia B S., Didi D A., Nita A. (2012). Pengambilan Minyak Kedelai Dari Ampas Tahu Sebagai Bahan Baku Pembuatan Biodiesel. Jurnal Ilmu Lingkungan. 10, 49-53.

Dahruji., Pipit F W., Totok H. (2017). Studi Pengolahan Limbah Usaha Mandiri Rumah Tangga dan Dampak Bagi Kesehatan di Wilayah Kenjeran. Aksiologiya: Jurnal Pengabdian Kepada Masyarakat. 1, 36-44.
Hadi, A. (2005). Prinsip Pengelolaan Pengambilan Sampel Lingkungan. Jakarta: PT Gramedia Pustaka Utama.

Kaswinarni, F. (2007). Kajian teknis pengolahan limbah padat dan cairIndustri tahu. Tersedia dari Diponegoro University Institutional Repository. (ID Code: 17407).

Sarengat N., Arum Y., Ike S., Suyatni. (2015). Kajian Potensi Pencemaran Industri pada Lingkungan Perairan di Daerah Istimewa Yogyakarta. Prosiding Seminar Nasional Kulit, Karet dan Plastik. 04, 131-155.

Wiryani, Erry. (2010). Analisis Kandungan Limbah Cair Pabrik Tempe. Jurnal ekologi dan Biosistematik. 1, 1-10. 